\title{
"Gawęda radiowa". The Works by Masters of Talk Radio (Using the Examples of Selected Shows from the Polish Branch of RFE)
}

To Professor Barbara Bogolębska, reminiscing on the old masters of words

\section{Initial remarks}

The term "gawęda radiowa," a genre almost gone from the media of today, was present in radio from its beginning, though it was often referred to with such interchangeable genre designations as "chat" (pogadanka) or "editorial" (felieton). A similar confusion also existed in other cases, e.g. the reviews by Jerzy Stempowski aired by the Polish branch of RFE in 1961-1968 were often announced as "chats" or "editorials." That could have indicated both the genological deficiencies of the radio hosts, and the affinity between the genres.

According to Stefania Skwarczyńska, the "threefold forms" which exist in genology, i.e. the genological object, the genological notion, which reflects it in cognitive terms, and the genological name, must be correlated to one another. She argued that "science must set certain conditions of the correctness of their structures and their application, so that they can be introduced into its area."' Therefore, let us, using some examples taken from the station's shows, in particular from the first

* Professor of the university, Ph.D. hab., University of Lodz, Faculty of Philology, Chair of Journalism and Social Communication, e-mail: konrad.tatarowski@uni.lodz.pl.

1 S. Skwarczyńska, "Niedostrzeżony problem podstawowy genologii", [in:] Problemy teorii literatury, selection H. Markiewicz, Ossolineum, Wrocław 1967, p. 147 [Unless indicated otherwise, English quotations were translated from Polish]. 
decade of its operations, and from the ethos and history of interwar radio, attempt to clarify the genre characteristics of "gawęda radiowa."

Prior to becoming a literary genre, "gawęda" had developed from oral folk works. As defined in Słownik terminologii medialnej:

its determining features are the omnipotent presence and position of the narrator, who draws knowledge on events from their own experience or the experiences of other participants or witnesses. The narrator does not observe the chronology of events, and introduces side plots and digressions, and offers a subjective point of view [...] Some features of gawęda (narrativeness, subjectivity, digressiveness, loose structure, connotative function) are also common for editorials [...]. ${ }^{2}$

Unlike in the case of literary "gawęda", which has been widely discussed in the scholarly literature, ${ }^{3}$ the radio version is distinctive because of the identity of the author and narrator. One characteristic of the literary version is the "intentional artistic detachment between the author and the narrator, the epic intermediary [...] who is inferior in intellectual and cultural terms to the author," ${ }^{\text {" }}$ which enables this narrative form to be used for parody or grotesque purposes, some examples of which can be found in the works of Nicolai Gogol or Witold Gombrowicz.

On the radio, the author is the person delivering their monologue, referring to their own experiences and observations, and thus, metaphorically speaking, they place their "author's seal" on the broadcast, adding credibility to the content being communicated. And, significantly enough, the author adds concreteness, in their own and unique manner, to use Roman Ingarden' ${ }^{5}$ terminology, to the linguistic and audio layer of the work. If printed in the press or a book, the same text would lose those special qualities, though it would retainits stylistic and structural specificity.

\section{Talk radio by Zygmunt Nowakowski}

Talk radio shows by Zygmunt Nowakowski, which could easily fit the genre variant of historical or historical-literary gawęda, were devoted to Polish rulers or men of letters, from MikołajRej to Stanisław Wyspiański and Stefan Żeromski. They were broadcast from the beginning of the Polish branch of RFE in 1952 until the early 1960s (the writer died in London in 1963). Nowakowski's aim was to "radioise" his discussions and adjust them to the needs and perception of listeners. That was

2 Słownik terminologii medialnej, W. Pisarek (ed.), Universitas, Kraków 2006, p. 67.

3 Vide B. Makowski, "Gawęda", [in:] Słownik rodzajów i gatunków literackich, G. Gazda, S. Tynecka-Makowska (eds.), Universitas, Kraków 2006, pp. 270-273.

4 Ibid., p. 271.

5 Vide R. Ingarden, "Z teorii dzieła literackiego", [in:] Problemy..., pp. 7-59. 
supposed to be achieved by the style of gawęda: free, easy-flowing, and filled with digressions.

The world depicted in gaweda, as per the rules of the genre, had to be as close to listeners as possible. For that end, the shows included both quotations from historical sources, and fragments of the works by the writers being discussed with explanations. The narrator usually presented himself as a participant of the events he was discussing. Nowakowski did not, obviously, witness the Baptism of Poland nor did he accompany Mikołaj Rej in writing Figliki, yet in both radio series, i.e. historical and literary, he displayed huge personal engagement and passion for the topics being discussed.

Nowakowski's Gawędy pod dębem [Talks under the oak tree], later published in book form in London in 1966, with a foreword by Leopold Kielanowski, were of a historical nature and in the RFE programming it was listed under the title: History by Radio. They were aired in 15-minute instalments from 19 December 1952 to June 1956. They formed a series of 177 talk radio shows, which covered Polish history from Mieszko I to the November Uprising and the Great Emigration.

Kielanowski described them as follows in his book:

Nowakowski's talk radio shows were like letters, written to his beloved... down on his knees. [...] they were created in the years of the darkest Stalinist night, which enveloped our country; in the years when the proverbial "iron curtain" cut Poland off from the West and prisons were full of people whose only crime was their love for their homeland. ${ }^{6}$

When discussing the literary and radio qualities of Nowakowski's shows as texts belonging to the spoken language, Kielanowski wrote:

The sentence rhythm, the arrangements of words, the selection of terminology for the phonetic qualities of individual words, the ascending and descending speech cadence in line with the psychophysical rules of the spoken language-all those elements formed the texts, created chiefly for them to be read aloud. ${ }^{7}$

The series was continued in a broadcast under the title Literature by Radio. Their author gave them the title Stowo polskie nasz chleb niepowszedni [Polish word. Our not so daily bread], but the title was not always used in radio announcements. The shows in the series were broadcast, also in 15-minute instalments, on the Polish branch of RFE from 24 June 1956. The series began with a talk radio show entitled Poczatek mowy polskiej [The beginning of Polish speech], and the final show was devoted to Michal Bałucki.

6 L. Kielanowski, "Wieczory pod dębem", Na Antenie 1965, issue 33, p. 6.

7 Ibid. 
The show was usually announced as "radio chats on the history of Polish literature", sometimes with a warmer, more personal touch:

And now, Ladies and Gentlemen, Zygmunt Nowakowski, the favourite columnist and talk radio host of all émigrés. As on any other Sunday, he is going to talk about literature by the fireplace in his London apartment. Title: Słoneczko śliczne oko [Sun, the lovely eye], or on the poetry of Lviv's Szymon Szymonowicz (announcement of 20 Jan 1957).

Nowakowski began the series with talks on the lives and outputs of chroniclers (Kadłubek, Janko z Czarnkowa, Długosz, and others), and the first Polish writers: from Biernat z Lublina (2 Sep 1956), through Rej, Kochanowski, Szymonowicz, later Kniaźnin and Franciszek Karpiński (2 Mar 1958), Fredro and the grand Romantics (between May 1958 until the autumn of 1960), to the works from the late $-19^{\text {th }}$ century and the beginning of the $20^{\text {th }}$ century (Sienkiewicz, Reymont, Żeromski, Wyspiański).

\section{Alfred Zbyszewski, the author of talk radio shows}

Another type of talk radio, thematically set in contemporary times and closer to an editorial, a letter from a journey, or even a reportage, was offered on RFE by Wacław Alfred Zbyszewski, a collaborator of the Paris-based Kultura, and a correspondent of Voice of America before that.

His My journey through Europe show was broadcast by Station 2 from September 1958. Initially, it was broadcast once a week (on Tuesdays, for 15 minutes), and later, i.e. from 1960, twice a week, but in shorter 10-minute instalments. Zbyszewski's show remained on air until the end of the 1970s, i.e. for over twenty years.

In line with the title, he talked about his travels to various European countries and about what he found significant enough to be worth sharing with his Polish listeners. He talked about fashion, about how and where people worked, about agricultural and industrial policies, about architecture, monuments and art galleries. He discussed local cuisine, politics and the economy, tourism, painting, universities and intellectual life. He talked in an interesting manner, with passion, from the position of an observer rather than as a participant of the western world. He usually talked about France and Paris, and England and its capital, but also about such countries as Switzerland, Greece, Italy, Turkey and the Netherlands.

\section{Tadeusz Nowakowski, (the last?) master of talk radio}

Tadeusz Nowakowski continued the traditions of talk radio in the final period of the Polish branch of RFE's operation. After he retired from radio, he continued to host a weekly talk radio show Przy kawiarnianym stoliku [By the café table]. 
His characteristic digressiveness, recalling distant memories through associations, sometimes based only on his personal experiences, his sense of humour, and his habit of often inserting various anecdotes, defined the atmosphere and the specificity of those 15 -minute shows. Talk radio shows by Tadeusz Nowakowski, unlike the previously mentioned historical or historical and literary shows by Zygmunt Nowakowski, drew on the author's biography and experience, his world of values, and his personal reflection. The final element had defined, of course, the specificity of Zygmunt Nowakowski's shows, though they were based on historical and source material, read as if from a singular author's point of view.

Tadeusz Nowakowski created his Przy kawiarnianym stoliku shows from 9 February 1977, on an irregular basis in the first years. Initially, those included chats with invited guests, e.g. he talked with Jan Kott on theatre (8 Jun 1977), with Lidia Ciołkoszowa on the Polish socialist movement (8 Jul 1977), and with Józef Czapski on his paintings (1 Jan 1979). As time went by, the shows started to become a one-man show, i.e. Nowakowski, who shared his literary fascinations (on Herbert's poetry 22 May 1988, on Bruno Schultz 17 May 1992)and political observations (Porozmawiajmy o Chruszczowie [Let's talk about Khrushchev], 25 Sep 1988); he talked about himself (Czy Olsztyński to Olsztyński ${ }^{8}$ [Is Olsztyński really Olsztyński], 27 Sep 1981) or about the institutions, places and people to whom he was connected (Wokół inauguracji Rozgłośni [On the establishing of the Station], a talk radio show created in celebration of the $40^{\text {th }}$ anniversary of the Polish branch of RFE, 22 Mar 1992). His final, 150 th Przy kawiarnianym stoliku show (entitled Czy Pan mówi po poznańsku [Do you speak Poznanian?] was aired on 6 November 1993, i.e. six months prior to the closure of RFE.

He applied a personal touch, i.e. artful and intriguing for listeners, to his recollections on his friends who had passed away: Wojciech Trojanowski (26 Feb 1988), and over a dozen years prior to that Zygmunt Nowakowski (17 Nov 1963) and Czesław Straszewicz (20 Oct 1963). In his recollections on Nowakowski, published in the London-based Wiadomości, ${ }^{9}$ Tadeusz Nowakowski quoted Zygmunt's words: "I wonder will there be any émigré who will be able to put a few words together over my grave. I feel that I would do that best," and he went on to comment: "That is true. The most beautiful recollection of Mr. Zygmunt could be uttered by only one golden-tongued orator, the master of restrained pathos, the sentimental bard, the kind poet, the one and only Zygmunt Nowakowski."'10

One could say without a moment's hesitation that Tadeusz Nowakowski inherited those abilities after Zygmunt Nowakowski, though, in fact, they were in

8 "Tadeusz Olsztyński" was Nowakowski's radio nom de plume, derived from his place of birth: Olsztyn.

9 T. Nowakowski, "Extra Cracoviam non est vita", Wiadomości 1963, issue 49 (923), p. 1.

10 Ibid. 
no way related. This is how he bid farewell to Czesław Straszewicz, his friend from radio:

Czesio is dead! I can still hear his voice in my head. I can still hear his friendly giggle of the surprised kind. I can still see the kind and friendly sparkle in his eyes, which I have always associated with an image from my childhood: a tame St. Bernard with a small barrel of cognac strapped to his neck rushing to help."

An exceptional combination, a comparison which can be justified only with the recesses of the author-narrator's memory. Further in his discussion, he described Straszewicz, with whom he remained in close and friendly relations:

We spent several years in the office, "glebae adscripti", by the same desk, tied to the same oar. We lived in the same house, on the sixth floor, only separated by a thin wall through which you could hear every word. We even shared a small balcony divided with a sailcloth, which in sunlight shimmered with the reflections of myriads of empty bottles of the fool proof medication which the prudent Pole in exile takes against losing their national identity. ${ }^{12}$

He described various life situations; some were funny, grotesque even, e.g. when he told of the circumstances in which Straszewicz was fired from the position of a warehouse operative in a factory in Uruguay. When the layoffs came, the author of Turyści z bocianich gniazd was also included in the list of workers to be laid off. The justification of the decision read: “'Ceslao Straszewicz - illiterate'... I am the only Polish writer, Czesio would brag, laughing, who was certified as illiterate in writing!"13 After offering the anecdote, Nowakowski proceeded to a witty and learned discussion of his friend's writings though maintained in a casual and vivid tone, and concluded the show in dark tones, referring to the writer's mortal sickness and the circumstances of his departure, shortly before his death, from Munich to Uruguay, and bid farewell to him in the "old and simple way, which has not changed for generations, in which Poles scattered throughout foreign lands say goodbye: 'Sleep, dear friend, in the dark grave, and may you dream of Poland."'14

Was Tadeusz Nowakowski the last master of talk radio? That, of course, is something no one can know for sure, as the future remains an open book. But until now no continuators of that type of expression, that manner of establishing contact with listeners, that ability to draw them into an original monologue, have

\footnotetext{
11 T. Nowakowski, "Czesio", Na Antenie 1963, issue 7, p. 4.

12 Ibid.

13 Ibid.

14 Ibid.
} 
been heard on the Polish radio, or seen on Polish television, as the masters of talk radio also appeared on TV (thereby enriched with the visual and illustrative element, though words still played a dominant role).

\section{Masters of talk radio in Polish radio and television: Jerzy Waldorff and Boguslaw Kaczyński}

Jerzy Waldorff, a writer and a specialist on music, was employed by Polish Radio until 1976, when he got fired after signing the famed "Letter of the 59" against the changes to the constitution of the People's Republic of Poland (PRL), which introduced an indissoluble and perpetual alliance with the USSR and the leading role of the Polish United Workers' Party (PZPR) in the PRL. He hosted various radio shows on music, but it was through television that he became famous. He hosted television shows about major figures from the past: in the 1960s in a the Spotkania $z$ cieniem [Meeting the shadows] series he talked about, e.g. Hanka Ordonówna, Jan Kiepura and other star singers, and later, in the 1970s in the Z muzyka przez lata [With music through the years] series he talked about classical music composers, e.g. Karol Szymanowski, Stanisław Moniuszko and the Wieniawski brothers. He even continued his work in the 1990s with the Polowy na rzece wspomnien [Fishing in the river of memories] series, where he discussed music events and major figures in the world of music from the $19^{\text {th }}$ century tothe interwar period.

His programmes were a "one-man show" dominated by the narrator who spoke in a charismatic low voice with a special modulation. For a few years he was accompanied by his beloved dachshund Puzon [Trombone] and he kept his trusty elegant walking stick finished with a silver ball by him. He spoke with a pleasant flow, colourfully, often inserting digressions and anecdotes, and thus indicating his knowledge.

Bogusław Kaczyński continued his radio and television activities. From 1970 he was the musical commentator on Polish radio and television. In his television shows Qui pro quo (1974-1978) and later Zaczarowany świat operetki [The enchanted world of operetta], he, too, was the leading figure, and in his long monologues he discussed the world of star singers, composers and authors of librettos, their impresarios, and he introduced viewers into the atmosphere and the specificity of the world of art and artistic life. One could assume that Waldorff and Kaczyński managed to "infect" many later concert hall and musical theatre goers with their passion and engagement.

\section{Final remarks}

Radio gawęda or talk radio and its televisual expansion belong to a dying breed. There is no place for it in the programming of either public or private media, not even in the electronic media. Topical debate and cultural shows are dominated by 
short commentary or editorial forms, and if a topic is discussed in more detail, it is usually through an interview or a debate with several participants. In the uniform standardised mode of communication, even though there is a thematically and ideologically diverse world of the media, the humanistic individual perspective is becoming extinct. There may be several reasons for this and a discussion of those could develop into a separate article. In this paper I only intended to indicate the need to state that both contemporary radio and contemporary television are beginning to lack any long personalised, subjective forms of expression, and expressive media personalities are getting lost along the way.

\title{
Bibliography
}

Ingarden R., "Z teorii dzieła literackiego", [in:] Problemy teorii literatury, selection of works H. Markiewicz, vol. 2, Ossolineum, Wrocław 1967, pp. 7-59.

Kielanowski L., "Wieczory pod dębem”, Na Antenie 1965, issue 33, p. 6.

Makowski B., "Gawęda", [in:] Słownik rodzajów i gatunków literackich, G. Gazda,

S. Tynecka-Makowska (eds.), Universitas, Kraków 2006, pp. 270-273.

Nowakowski T., "Czesio", Na Antenie 1963, issue 7, p. 4.

Nowakowski T., "Extra Cracoviam non estvita”, Wiadomości 1963, issue 49 (923), p. 1. Skwarczyńska S., "Niedostrzeżony problem podstawowy genologii”, [in:] Prob-

lemy teorii literatury, selection H. Markiewicz, Ossolineum, Wrocław 1967, pp. 145-164.

Słownik terminologii medialnej, W. Pisarek (ed.), Universitas, Kraków 2006.

Konrad W. Tatarowski

\section{Gawęda radiowa - dzieło mistrzów mikrofonu (na przykładzie wybranych audycji Rozgłośni Polskiej RWE)}

\author{
Streszczenie
}

Artykuł zawiera definicję i charakterystykę gawędy radiowej w porównaniu z gawędą literacką oraz omówienie różnych odmian gatunkowych gawędy radiowej na przykładach twórczości mikrofonowej Zygmunta Nowakowskiego, Alfreda Zby- 
szewskiego i Tadeusza Nowakowskiego, a także telewizyjnych programów Jerzego Waldorffa i Bogusława Kaczyńskiego.

Słowa kluczowe: gawęda radiowa, gatunki radiowe, pisarze w Rozgłośni Polskiej RWE.

\title{
"Gawęda radiowa". The Works by Masters of Talk Radio (Using the Examples of Selected Shows from the Polish Branch of RFE)
}

\author{
Summary
}

The article includes a definition and a description of radio gawęda (or talk radio show) in comparison to the literary gawęda, and a discussion of its various genre variants, using the examples of radio shows by Zygmunt Nowakowski, Alfred Zbyszewski, and Tadeusz Nowakowski, and the television shows by Jerzy Waldorff and Bogusław Kaczyński.

Keywords: radio chat, radio genres, Polish Brodcaster RFE.

Konrad Witold Tatarowski - Ph.D. hab., professor of the University of Lodz, literary scientist and media researcher, author of articles, poet and literary critic. Author of the books: Światło w ciemności (1993, zbiór poetycki), Literatura i pisarze w programie Rozgłośni Polskiej RWE (2005), Aksjologia i polityka w pisarstwie i działalności Jana Nowaka-Jeziorańskiego (2010), Niezależna literatura i dziennikarstwo przed 1989 rokiem. Idee - ludzie - spory (2016), Liryka i polityka. Jacek Bierezin, Zbigniew Dominiak, Zdzisław Jaskuła, Witold Sułkowski - o twórczości poetów podziemnego pisma „Puls” (co-author: R. Nolbrzak, 2019) and a few dozen papers in monographs and academic journals on the literary life of the emigrant community, the Polish branch of RFE, samizdat in PRL, and the literature of the $20^{\text {th }}$ and $21^{\text {st }}$ centuries. Author of various papers in emigration and domestic journals, as well as of radio drama and radio reportage. 